\title{
Advancing Leadership and Followership Education with a Leader-Follower Unity Model
}

\author{
Evgenia V. Prilipko \\ Texas State University
}

Leaders and followers are equally important for organizational success. Therefore, it is essential to educate individuals to become effective leaders and followers. In this work, a taxonomy of leadership theories with the follower component is developed to acknowledge the presence of followers in the leadership process. A Leader-Follower Unity model is proposed to portray an individual's ability to act as a leader and a follower. The importance of teaching leadership from a Leader-Follower Unity standpoint is addressed. An implementation of a Leader-Follower course teaching both leader and follower skills is suggested.

\section{INTRODUCTION}

The idea of leaders as heroes and symbols of power, wisdom, knowledge, and authority, and followers as dependents prevails in the society. It is not well recognized that these characteristics are ascribed to leaders by followers, similar to Max Weber/Robert House's concept of charisma when followers fervently attribute super powers (exceptional traits or qualities) to their leaders (Boone \& Bowen, 1987; Ciulla, 2004; Gardner, 1987; Hollander, 1992; Nahavandi, 2009). "Emphasizing leadership to the exclusion of followership breeds a single-minded conformism" (Kelley, 1992, p. 9). In order to understand why organizations fail, freeze, or succeed, it is imperative to step away from the notion of leadership and expose follower attributes to the spotlight.

The study of followership until very recently has been largely neglected (Adair, 2008; Baker, 2007; Bjugstad, Thach, Thompson, \& Morris, 2006; Brumm \& Drury, 2013; Carsten, Uhl-Bien, West, Patera, \& McGregor, 2010; Cox III, Plagens, \& Sylla, 2010; Kellerman, 2008; Kelley, 2008; Lundin \& Lancaster, 1990; Sy, 2010; Tee, Paulsen, \& Ashkanasy, 2013; Uhl-Bien, Riggio, Lowe, \& Carsten, 2014). Bligh (2011) notes that throughout the 19-year timeframe from 1990 to 2008 only as little as 14 percent of the articles contained the term follower in the abstract or title in The Leadership Quarterly.

A profound work on followership began in 1955 with publications by Hollander and associates, followed by Gardner's (1987) Leaders and Followers, Kelley's (1988) article in Harvard Business Review In Praise of Follower, and a seminal Joseph Rost's (1991) book Leadership for the Twenty-First Century. In his book The Power of Followership, Kelley (1992) posed questions: "Why... do people tend to value leaders and undervalue followers? Why do we refuse to appreciate that follower are us [emphasis in original]?" (p. 8).

Since then, appreciation of followership as a vital component of the leadership process has escalated significantly (Adair, 2008; Kellerman, 2008; Riggio, Chaleff, \& Lipman-Blumen, 2008). The first 
national conference on followership took place in 2006 at Claremont McKenna College and continues to serve its academic and research purposes. Thousands of master's theses and doctoral dissertations have addressed followership in areas ranging from nursing, education, business, sports, hotel industry, and others.

Although an impressive number of workshops, training sessions, and courses are offered on cultivating leadership skills, corresponding to Gardner's (1987) belief that 90 percent of leadership can be taught, emphasis on teaching the followership component of the leadership process remains slim. While the first course on followership was offered at Carnegie-Mellon University by Robert Kelley in 1985 (Kelley, 1992, p. 36), availability of such courses at other universities in the United States to this day is limited.

In 2014, Malakyan conducted a quantitative analysis of the undergraduate residential leadership programs (53 majors and 17 minors) in the United States to determine whether followership constitutes a part of their curricula (Malakyan, 2014). Seventy universities (26 state, 19 private, and 25 faith-affiliated institutions) were randomly selected out of 200 programs listed in the Directory of Leadership Programs by the International Leadership Association. Out of 70 institutions, none had a course on followership or had followership mentioned in the program descriptions.

\section{TAXONOMY OF LEADERSHIP THEORIES WITH THE FOLLOWER COMPONENT}

A comprehensive review of leadership theories resulted in a list of selected theories that incorporate various aspects of followership as its integral element. These theories are presented in Table 1 and are arranged in a historical order of leadership theory development: The Contingency Era (early 1960s to present) and Contemporary/New Models for Leadership (1970s to present) (Boone \& Bowen, 1987; Burns, 1978; Nahavandi, 2009). The role of followers within each theory is indicated. The purpose of this taxonomy is to reflect the presence of followers within the leadership process as acknowledged in each leadership theory and emphasize that leadership is inconceivable without followers.

A prevailing number of existing leadership theories are based on a leader-centric approach. These theories acknowledge the presence of followers, but do not place them in equilibrium with the leaders. Avolio and Reichard (2008) note that parallel to authentic leadership, there is authentic followership: "Authentic followership develops from modeling by the authentic leader and likely vice versa, depending on the qualities and capabilities of the follower, which produces heightened levels of follower and leader self-awareness" (p. 327). Bass and Riggio (2006) and Uhl-Bien, Riggio, Lowe, and Carsten (2014) affirm that transformational leadership remains the most researched leadership theory as transformational leaders focus on followers' needs, but still fail to fully acknowledge the attributes or contribution of the followers. Thus, a question of which theory places a bigger emphasis on the importance of followers may still be a question of controversy and various interpretations among scholars.

After reviewing the fundamental leadership theories, the question arises whether any theories on followership exist. In 2014 the first formal theory of followership was proposed by Uhl-Bien et al. The theory encompasses: (a) a follower role (position of a follower in relation to leaders), (b) following behaviors (in relation to leaders), and (c) outcomes related to the leadership process. The authors further propose that the following dimensions could be included in the study of followership: (a) followership characteristics, (b) followership behaviors, and (c) follower outcomes (Uhl-Bien et al., 2014).

\section{LEADER-FOLLOWER UNITY MODEL}

As shown in Table 1, the leadership theories that incorporate various aspects of followership mainly focus on the role and characteristics of the leader, leaving insignificant room for the role of followers. Thus, textbooks and courses with a heavy emphasis on leadership breed a perception of inequality in the roles, with leaders being exalted and followers diminished, as portrayed in Figure 1.

Extensive research supports that individuals play leader and follower roles interchangeably (Baker, Mathis, \& Stites-Doe, 2011; Chaleff, 2009, 2010; Cox III et al., 2010; Howell \& Mendez, 2008; 
Kellerman, 2012; Kelley, 1988, 1992; Malakyan, 1998, 2014; Rost, 1991, 1995). Each individual acts as a leader in one situation and a follower in another. Based on this premise, a model of Leader-Follower Unity (LFU) is proposed to portray an individual's ability to act as a leader or a follower, depending on the context.

TABLE 1

TAXONOMY OF LEADERSHIP THEORIES WITH THE FOLLOWER COMPONENT

Theory Author and Year Follower Component

Contingency Models (early 1960s to Present)

Contingency Model

Path-Goal Theory

Situational Leadership

Theory (SLT),

previously known as

Life-Cycle Theory

of Leadership, 1969

Normative Decision Model (Vroom-Yetton Model)

Substitutes for Leadership Model (SLM)

Leader-Member Exchange Theory (LMX)
Fred Fiedler, 1967

Robert House, 1971

Ken Blanchard, Paul Hersey, 1972

Victor Vroom, Philip Yetton, Arthur Jago, 1973

Steven Kerr, John Jermier, 1978

George Graen, Mary Uhl-Bien, 1995
Followers facilitate an identification of a leader's individual leadership style. A proper match is desired between a leader's style of interacting with followers.

Followers' obstacles are reduced and they are provided with resources necessary to achieve organizational goals.

Leadership effectiveness depends on the level of followers' readiness (the degree to which followers are able and willing to accomplish a task).

Followers' commitment plays an important role in the process of the leader's decision-making.

Certain organizational or individual variables such as followers' training or expertise can substitute for leadership.

Followers are divided between the in-group (closer to the leader) and out-group (farther from the leader). The in-group followers benefit from a higher level of leader's attention, rewards, and job satisfaction. 
TABLE 1-CONTINUED

TAXONOMY OF LEADERSHIP THEORIES WITH THE FOLLOWER COMPONENT

Theory Author and Year Follower Component

Contemporary/New Models for Leadership (1970s to Present)

\begin{tabular}{|c|c|c|}
\hline $\begin{array}{l}\text { Charismatic Leadership } \\
\text { Theory }\end{array}$ & $\begin{array}{l}\text { Max Weber, } \\
1924, \\
\text { Robert House, } \\
\text { 1977, } \\
\text { James McGregor } \\
\text { Burns, } \\
1978\end{array}$ & $\begin{array}{l}\text { Followers ascribe } \\
\text { extraordinary qualities or abilities } \\
\text { to the leader. A leader is considered } \\
\text { charismatic solely based on the followers' } \\
\text { perception. }\end{array}$ \\
\hline $\begin{array}{l}\text { Transactional Leadership } \\
\text { Theory }\end{array}$ & $\begin{array}{l}\text { James McGregor } \\
\text { Burns, } \\
1978\end{array}$ & $\begin{array}{l}\text { Support of followers is exchanged } \\
\text { for incentives, and, therefore, may } \\
\text { be perceived as manipulated. }\end{array}$ \\
\hline $\begin{array}{l}\text { Transformational } \\
\text { Theory }\end{array}$ & $\begin{array}{l}\text { James McGregor } \\
\text { Burns, } \\
1978\end{array}$ & $\begin{array}{l}\text { Followers are inspired by their } \\
\text { highly moral leaders to direct } \\
\text { their efforts towards a common } \\
\text { goal for the overall good } \\
\text { of the organization. }\end{array}$ \\
\hline Servant Leadership Theory & $\begin{array}{l}\text { Robert Greenleaf, } \\
1978\end{array}$ & $\begin{array}{l}\text { Followers are being "served" by } \\
\text { leaders, as found in ancient } \\
\text { Eastern and Western beliefs. } \\
\text { Servant leaders lead because they } \\
\text { aim to serve their followers. }\end{array}$ \\
\hline $\begin{array}{l}\text { Authentic Leadership } \\
\text { Theory }\end{array}$ & $\begin{array}{l}\text { Bill George, } \\
2003\end{array}$ & $\begin{array}{l}\text { Followers have faith and trust in } \\
\text { their leaders. They find them moral, } \\
\text { candid, and ethical, and develop } \\
\text { strong bonds with the leader. }\end{array}$ \\
\hline Team Leadership & $\begin{array}{l}\text { Susan Kogler } \\
\text { Hill, } \\
2007\end{array}$ & $\begin{array}{l}\text { Followers constitute teams, and } \\
\text { teams and leadership processes } \\
\text { reciprocally influence each other. }\end{array}$ \\
\hline
\end{tabular}




\section{FIGURE 1 \\ HEAVY EMPHASIS ON LEADERSHIP IN TEACHING}

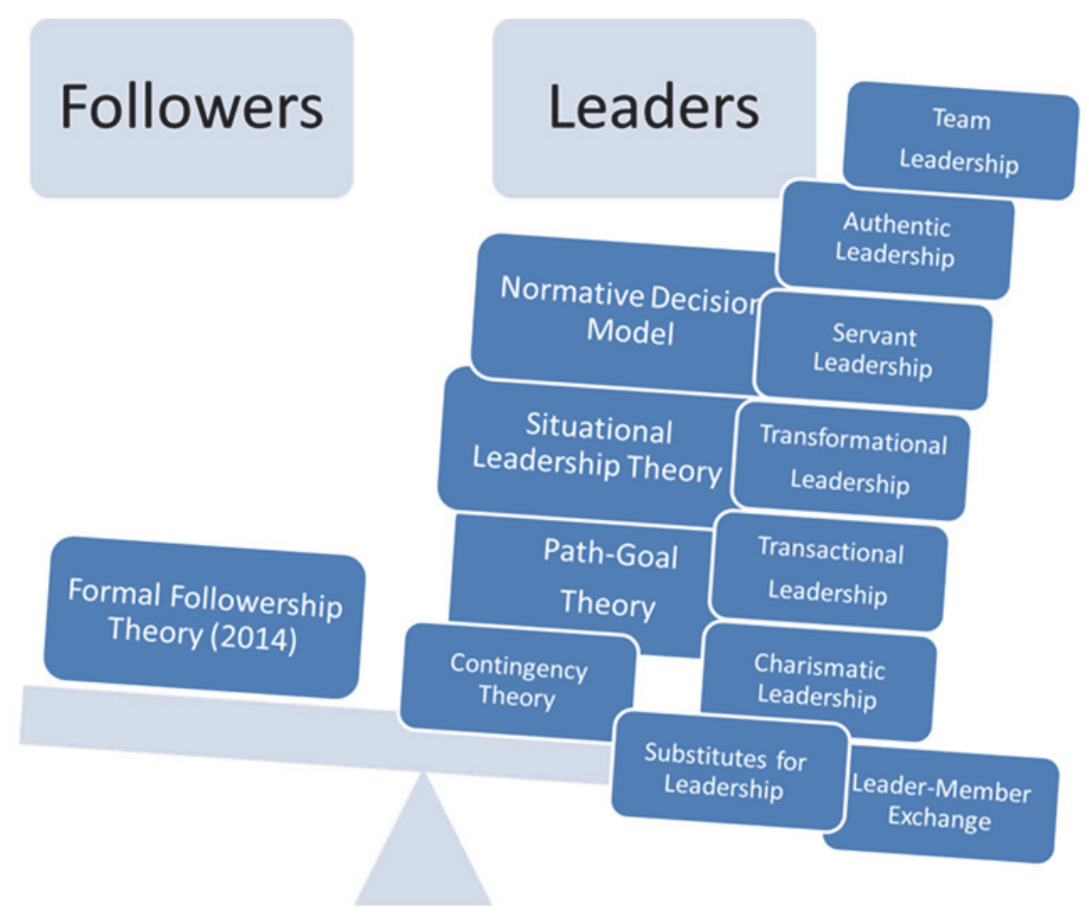

Teaching from an LFU standpoint enables practitioners to embrace the criticality of both sides and address the differences, needs, and attributes of leaders and followers. When applied to teaching leadership-followership courses, LFU recognizes that both components are equally weighted. The attributes, however, may not be identical for leaders and followers (the quest that has been approached and remains an avenue for further exploration), but are overlapping. This is shown in Figure 2. While some of them are commonly desired characteristics (attributes characteristic to both leaders and followers) (Baker et al., 2011; Hemphill \& Coons, 1950; Hollander, 1992; Kellerman, 2008; Kelley, 1988; Lundin \& Lancaster, 1990; Nolan \& Harty, 1984; Stogdill \& Coons, 1957), the other attributes are particular to leaders or followers to a different extent (Antelo, Henderson, \& St. Clair, 2010; Antelo, Prilipko, \& Sheridan-Pereira, 2010; Baker et al., 2011; Henderson, 2008; Henderson \& Antelo, 2007; Hollander, 1992; Prilipko, Antelo, \& Henderson, 2011; Sy, 2010).

Leader and follower attributes need to be integrated into the course material and should be undergirded in classical elements of theory so that when a theoretical concept is reviewed, it is approached from the dual standpoint - that of a leader and a follower. Therefore, when applying LFU to practice, it is important to distinguish between the attributes (a) important for leaders, (b) important for followers, and (c) equally important for leaders and followers. Also, the depth and criticality of an attribute of a leader or a follower would depend on the context. 
FIGURE 2

\section{LEADER AND FOLLOWER ATTRIBUTES-NOT IDENTICAL, BUT OVERLAPPING}

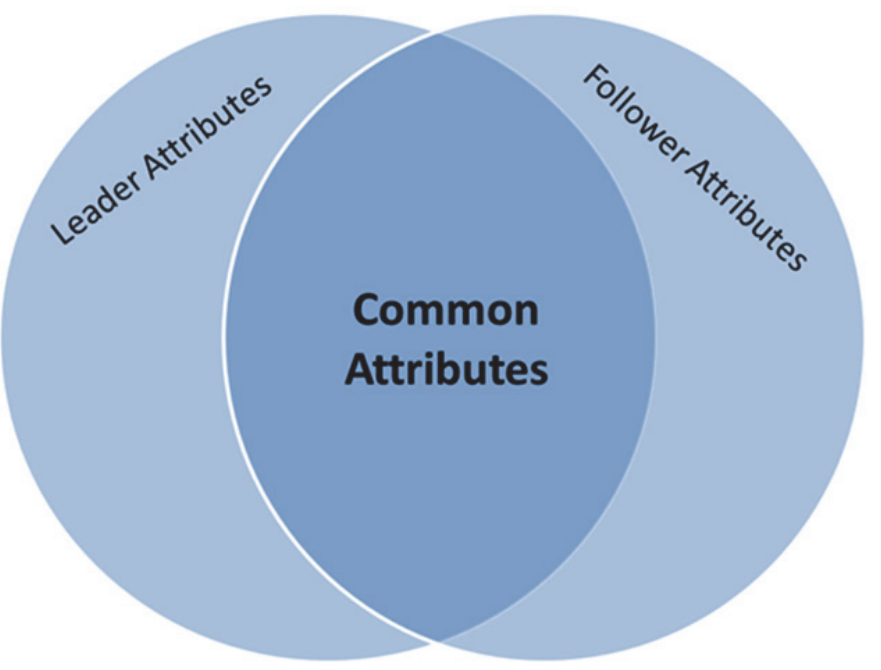

\section{CONCLUSION}

Followership has traditionally been neglected and understudied in the leadership literature. In this work, the taxonomy of leadership theories with the follower component was developed to acknowledge the presence of followers in the leadership process. The model of Leader-Follower Unity (LFU) was proposed to portray an individual's ability to act as a leader or a follower, depending on the context. Teaching from an LFU standpoint enables practitioners to embrace the criticality of both sides and address the differences, needs, and attributes of leaders and followers. When applied to teaching leadership-followership courses, LFU recognizes that both components are equally weighted. The attributes, however, may not be identical for leaders and followers, but are overlapping. These attributes should be integrated into the Leader-Follower course, linked with leadership theories, and approached from both the leader and follower standpoints. 


\section{REFERENCES}

Adair, R. (2008). Developing great leaders, one follower at a time. In R. E. Riggio, I. Chaleff, \& J. Lipman-Blumen (Eds.), The art of followership: How great followers create great leaders and organizations. San Francisco, CA: Jossey-Bass.

Antelo, A., Henderson, R. L., \& St. Clair, N. (2010). Understanding the process model of leadership: Follower attribute design and assessment. Journal of College Teaching \& Learning, 7(4), 9-14.

Antelo, A., Prilipko, E. V., \& Sheridan-Pereira, M. (2010). Assessing effective attributes of followers in a leadership process. Contemporary Issues in Education Research, 3(10), 1-12.

Avolio, B. J., \& Reichard, R. J. (2008). The rise of authentic followership. In R. E. Riggio, I. Chaleff, \& J. Lipman-Blumen (Eds.), The art of followership: How great followers create great leaders and organizations. San Francisco, CA: Jossey-Bass.

Baker, S. (2007). Followership: The theoretical foundation of a contemporary construct. Journal of Leadership and Organizational Studies, 14(1), 50-58. doi:10.1177/0002831207304343

Baker, S., Mathis, C. J., \& Stites-Doe, S. (2011). An exploratory study investigating leader and follower characteristics at U.S. healthcare organizations. Journal of Managerial Issues, 23(3), 341-363.

Bass, B. M., \& Riggio, R. E. (2006). Transformational leadership (2nd ed.). Mahwah, NJ: Lawrence Erlbaum.

Bjugstad, K., Thach, E. C., Thompson, K. J., \& Morris, A. (2006). A fresh look at followership: A model for matching followership and leadership styles. Institute of Behavioral and Applied Management, 7(3), 304-319.

Bligh, M. (2011). Followership and follower-centered approaches. In A. Bryman, D. Collinson, K. Grint, B. Jackson, \& M. Uhl-Bien (Eds.), The Sage Handbook of Leadership (pp. 425-436). London, England: Sage.

Boone, L. E., \& Bowen, D. D. (1987). The great writings in management and organizational behavior (2nd ed.). Boston, MA: Irwin McGraw-Hill.

Brumm, C. A., \& Drury, S. (2013). Leadership that empowers: How strategic planning relates to followership. Engineering Management Journal, 25(4), 17-30.

Burns, J. M. (1978). Leadership. New York, NY: Harper \& Row.

Carsten, M. K., Uhl-Bien, M., West, B. J., Patera, J. L., \& McGregor, R. (2010). Exploring social constructions of followership: A qualitative study. The Leadership Quarterly, 21, 543-562. doi:10.1016/j.leaqua.2010.03.015

Chaleff, I. (2009). The courageous follower: Standing up to and for our leaders (3rd ed.). San Francisco, CA: Berrett-Koehler.

Chaleff, I. (2010). Promoting the healthy flow of information to senior leaders. Leader to Leader, 56, 1216.

Ciulla, J. (2004). Ethics, the heart of leadership (2nd ed.). Westport, CT: Praeger.

Cox III, R. W., Plagens, G. K., \& Sylla, K. (2010). The leadership-followership dynamic: Making the choice to follow. The International Journal of Interdisciplinary Social Sciences, 5(8), 37-51.

Gardner, J. W. (1987). Leaders and followers. Liberal Education, 73(2), 4-6.

Hemphill, J. K., \& Coons, A. E. (1950). Leader behavior description. Columbus, OH: Personnel Research Board, Ohio State University.

Henderson, R. L. (2008). Back to the basics of leadership: Understanding leadership attribute assessment and development. Conference Proceedings of the International Conference on College Teaching. (\#240T). San Juan, Puerto Rico.

Henderson, R. L., \& Antelo, A. (2007). - The scholar practitioner: The view of practicing organizational leaders. Conference Proceedings of the International Conference on College Teaching. (\#306T). Venice, Italy.

Hollander, E. P. (1992). Leadership, followership, self, and others. The Leadership Quarterly, 3(1), 4354. doi:10.1016/1048-9843(92)90005-z 
Howell, J., \& Mendez, M. (2008). Three perspectives on followership. In R. Riggio, I. Chaleff, \& J. Lipman-Blumen (Eds.), The art of followership: How great followers create great leaders and organizations (pp. 25-40). San Francisco, CA: Jossey-Bass.

Kellerman, B. (2008). Followership: How followers are creating change and changing leaders. Boston, MA: Harvard Business School Press.

Kellerman, B. (2012). The end of leadership. New York, NY: Harper Collins Publishers.

Kelley, R. E. (1988). In praise of followers. Harvard Business Review, 66(6), 142-148.

Kelley, R. E. (1992). The power of followership: How to create leaders people want to follow and followers who lead themselves. New York, NY: Doubleday.

Kelley, R. E. (2008). Rethinking followership. In R. E. Riggio, I. Chaleff, \& J. Lipman-Blumen (Eds.), The art of followership: How great followers create great leaders and organizations. San Francisco, CA: Jossey-Bass.

Lundin, S. C. \& Lancaster, L. C. (1990, May-June). Beyond leadership: The importance of followership. The Futurist, 18-22.

Malakyan, P. G. (1998). Christ-like leadership: Theological and missiological foundations for leadership and development (Armenian case study) (Doctoral dissertation). Available from ProQuest Dissertations and Theses. (UMI No. 9833528)

Malakyan, P. G. (2014). Followership in leadership studies: A case of leader-follower trade approach. Journal of Leadership Studies, 7(4), 6-22. doi:10.1002/j1s.21306

Nahavandi, A. (2009). The art and science of leadership (5th ed.). Upper Saddle River, NJ: Pearson Education.

Nolan, J. S., \& Harty, H. F. (1984). Followership $\geq$ leadership. Education, 104(3), 311-312.

Prilipko, E. V., Antelo, A., \& Henderson, R. (2011). Rainbow of followers' attributes in a leadership process. International Journal of Management and Information Systems, 15(2), 79-94.

Riggio, R. E., Chaleff, I., \& Lipman-Blumen, J. (2008). The art of followership: How great followers create great leaders and organizations. San Francisco, CA: Jossey-Bass.

Rost, J. C. (1991). Leadership for the Twenty-First Century. Westport, CT: Praeger.

Rost, J. C. (1995). Leadership: A discussion about ethics. Business Ethics Quarterly, 5(1), 129-142. doi: $10.2307 / 3857276$

Stogdill, R., \& Coons, A. E. (1957). Leader behavior: Its description and measurement (Eds.). Columbus, $\mathrm{OH}$ : Bureau of Business Research, Ohio State University.

Sy, T. (2010). What do you think of followers? Examining the content, structure, and consequences of implicit followership theories. Organizational Behavior and Human Decision Processes, 113, 73 84. doi:10.1016/j.obhdp.2010.06.001

Tee, E. Y. J., Paulsen, N., \& Ashkanasy, N. M. (2013). Revisiting followership through a social identity perspective: The role of collective follower emotion and action. The Leadership Quarterly, 24, 902-918. doi:10.1016/j.leaqua.2013.10.002

Uhl-Bien, M., Riggio, R., Lowe, K. B., \& Carsten, M. K. (2014). Followership theory: A review and research agenda. The Leadership Quarterly, 25, 83-104. doi:10.1016/j.leaqua.2013.11.007 